\title{
Effects of Gadolinium-Based
} Contrast Agents on Thyroid Hormone Receptor Action and Thyroid Hormone-Induced Cerebellar Purkinje Cell Morphogenesis

OPEN ACCESS

Edited by:

Sheue-yann Cheng,

National Cancer Institute, USA

Reviewed by:

Tania M. Ortiga-Carvalho,

Federal University of

Rio de Janeiro, Brazil

Heike Heuer,

Leibniz Research Institute for Environmental Medicine, Germany

Ulrich E. M. Schweizer,

University of Bonn, Germany

*Correspondence:

Noriyuki Koibuchi

nkoibuch@gunma-u.ac.jp

tWinda Ariyani, Toshiharu Iwasaki, and Wataru Miyazaki contributed equally to this work.

Specialty section: This article was submitted to Thyroid Endocrinology,

a section of the journal

Frontiers in Endocrinology

Received: 12 April 2016 Accepted: 09 August 2016 Published: 26 August 2016

Citation:

Ariyani W, Iwasaki T, Miyazaki W, Khongorzul E, Nakajima T, Kameo S,

Koyama H, Tsushima $Y$ and Koibuchi N (2016) Effects of Gadolinium-Based Contrast Agents on Thyroid Hormone Receptor Action and Thyroid Hormone-Induced Cerebellar Purkinje Cell Morphogenesis.

Front. Endocrinol. 7:115. doi: 10.3389/fendo.2016.00115

\section{Winda Ariyani ${ }^{1+}$, Toshiharu Iwasaki ${ }^{1,2 t}$, Wataru Miyazaki ${ }^{1+}$, Erdene Khongorzul ${ }^{3}$, Takahito Nakajima ${ }^{3}$, Satomi Kameo ${ }^{4}$, Hiroshi Koyama ${ }^{4}$, Yoshito Tsushima ${ }^{3}$ and Noriyuki Koibuchi' ${ }^{*}$}

\footnotetext{
'Department of Integrative Physiology, Gunma University Graduate School of Medicine, Maebashi, Japan, ${ }^{2}$ Department of Liberal Arts and Human Development, Kanagawa University of Human Services, Kanagawa, Japan, ${ }^{3}$ Department of Diagnostic Radiology and Nuclear Medicine, Gunma University Graduate School of Medicine, Maebashi, Japan, ${ }^{4}$ Department of Public Health, Gunma University Graduate School of Medicine, Maebashi, Japan
}

Gadolinium (Gd)-based contrast agents (GBCAs) are used in diagnostic imaging to enhance the quality of magnetic resonance imaging or angiography. After intravenous injection, GBCAs can accumulate in the brain. Thyroid hormones (THs) are critical for the development and functional maintenance of the central nervous system. TH actions in brain are mainly exerted through nuclear TH receptors (TRs). We examined the effects of GBCAs on TR-mediated transcription in CV-1 cells using transient transfection-based reporter assay and $\mathrm{TH}$-mediated cerebellar Purkinje cell morphogenesis in primary culture. We also measured the cellular accumulation and viability of $\mathrm{Gd}$ after representative GBCA treatments in cultured CV-1 cells. Both linear (Gd-diethylene triamine pentaacetic acid-bis methyl acid, Gd-DTPA-BMA) and macrocyclic (Gd-tetraazacyclododecane tetraacetic acid, Gd-DOTA) GBCAs were accumulated without inducing cell death in $\mathrm{CV}-1$ cells. By contrast, $\mathrm{Gd}$ chloride $\left(\mathrm{GdCl}_{3}\right)$ treatment induced approximately 100 times higher $\mathrm{Gd}$ accumulation and significantly reduced the number of cells. Low doses of Gd-DTPA-BMA (10-8 to $\left.10^{-6} \mathrm{M}\right)$ augmented TR-mediated transcription, but the transcription was suppressed at higher dose $\left(10^{-5}\right.$ to $\left.10^{-4} \mathrm{M}\right)$, with decreased $\beta$-galactosidase activity indicating cellular toxicity. TR-mediated transcription was not altered by $\mathrm{Gd}$-DOTA or $\mathrm{GdCl}_{3}$, but the latter induced a significant reduction in $\beta$-galactosidase activity at high doses, indicating cellular toxicity. In cerebellar cultures, the dendrite arborization of Purkinje cells induced by $10^{-9} \mathrm{M} \mathrm{T}_{4}$ was augmented by low-dose Gd-DTPA-BMA (10-7M) but was suppressed by higher dose $\left(10^{-5} \mathrm{M}\right)$. Such augmentation by low-dose Gd-DTPA-BMA was not observed with $10^{-9} \mathrm{M} \mathrm{T}_{3}$, probably because of the greater dendrite arborization by $T_{3}$; however, the arborization by $T_{3}$ was suppressed by a higher dose of Gd-DTPA-BMA $\left(10^{-5} \mathrm{M}\right)$ as seen in $\mathrm{T}_{4}$ treatment. The effect of Gd-DOTA on dendrite arborization was much weaker than that of the 
other compounds. These results indicate that exposure to specific GBCAs may, at least in part, cause toxic effects in the brain by disrupting the action of THs on TRs. The toxic effects of GBCAs may depend on the chemical structure of GBCA and the dose. Thus, it is very important to choose appropriate GBCAs for imaging to prevent adverse side effects.

Keywords: endocrine disruption, cerebellum, neurotoxicology, development, T4, T3

\section{INTRODUCTION}

Gadolinium (Gd) is a heavy metal of the lanthanide group with an oxidation state of +3 and an ionic radius of $0.99 \AA$. The trivalent $\mathrm{Gd}$ ion $\left(\mathrm{Gd}^{3+}\right)$ exhibits cellular toxicity by inhibiting various $\mathrm{Ca}^{2+}$ channels through competitive binding with a much higher affinity than $\mathrm{Ca}^{2+}(1,2)$. In spite of their toxicity, Gd-chelated compounds, such as chelated organic Gd complexes, have been used as contrast agents in magnetic resonance imaging (MRI) and magnetic resonance angiography. Gd-based contrast agents (GBCAs) are chelated forms of Gd that are manufactured to reduce the toxicity of $\mathrm{Gd}$ by avoiding the presence of free $\mathrm{Gd}^{3+}$ (2). GBCAs are classified as linear or macrocyclic, according to their chelated structure, and as ionic or non-ionic, based on their ion charge $(1,3)$. In general, compared with linear types, macrocyclic GBCAs are more stable, tend to bind with Gd for longer durations, and have lower dissociation rates $(1,2,4)$.

In rodent studies, tissue deposition of Gd by GBCA exposure has been found in the skin, liver, kidney, lung, heart, and bones $(5,6)$. Once there, the low stability of GBCAs means that they may undergo transmetallation and release free $\mathrm{Gd}^{3+}$ by replacement with cations, such as zinc, iron, copper, and calcium. The released $\mathrm{Gd}^{3+}$ is then free to attach to endogenous anions, such as phosphate, citrate, hydroxide, and carbonate, and can deposit in tissues as insoluble compounds $(4,7)$. In some patients with renal insufficiency, exposure to GBCA is known to cause nephrogenic systemic fibrosis (NSF) $(8,9)$, and although the exact cause remains unclear, GBCA exposure activates toll-like receptor (TLR) 4 and TLR7-mediated gene expression, resulting in increased production of many cytokines, chemokines, and growth factors. These include transforming growth factor beta 1 (TGF- $\beta 1$ ) and interleukin-6 (IL-6) in macrophages, and increase production of collagens I and III, fibronectin, and hyaluronic acid in fibroblasts (8-10). As a result of the increased production of these factors, tissue inflammation and fibrosis are activated and may cause NSF.

Gadolinium deposition has also been found in brain tissue, even in patients without severe renal dysfunction (11). Specifically, the dentate nucleus and globus pallidus have shown significantly higher Gd accumulation than other brain regions (2, 12). Moreover, Gd induces cell death by inhibiting mitochondrial function and by inducing oxidative stress, followed by a rapid accumulation of reactive oxygen in primary cultures of rat cortical neurons $(13,14)$. By contrast, another study showed that administration of GBCAs does not cause any severe neurological alterations, such as seizures (15). On the other hand, long-term oral administration of other lanthanides affects functions of learning and memory, swimming and walking abilities, and touch response behavior in rats (16). Thus, although controversy still exists, lanthanides, including Gd, may cause neurotoxic effects in brain. However, the mechanism that causes the toxic effects of lanthanides may not be fully explained by the disruption of $\mathrm{Ca}^{2+}$ channels and mitochondrial function.

The thyroid hormones [THs; 3,5,3'-tri-iodo-L-thyronine (or $\mathrm{T}_{3}$ ) and thyroxine (or $\mathrm{T}_{4}$ )] play important roles in brain development, including the development of the cerebellum $(17,18)$. THs regulate various developmental processes from neuronal and glial proliferation to differentiation and neuronal migration in definitive brain regions (19). They also regulate the formation of neuronal cytoarchitecture and synaptogenesis (20). Thus, TH deficiency can change neuronal development and function. In addition, neuronal excitability and neurotransmitter transportation are also affected (21). Consequently, abnormal motor coordination, decreased locomotor activity, and increased anxiety have been observed in hypothyroid patients and experimental animal models (21). It should be noted that some of these phenotypes may also be observed in animals that are exposed to Gd compounds $(15,16)$.

Thyroid hormone actions are mainly mediated by nuclear $\mathrm{TH}$ receptors (TRs) that bind to a specific DNA sequence, called TH response element (TRE), as a homodimer or a heterodimer with the retinoid X receptor (RXR). TRs have two major isoforms, such as TR $\alpha$ and TR $\beta$, which are encoded by separate genes on human chromosomes 17 and 3, respectively. Both TR isoforms are expressed in adult and developing brains (22). The TR-RXR complex recruits a series of cofactors (corepressors and coactivators) in a ligand-dependent manner and regulates the transcription of target genes (22-24). TH target genes include functional proteins that regulate various brain development and maintenance processes as well as mitochondrial functions.

Two important areas of uncertainty exist in the research literature. First, although several heavy metals affect TH activity $(25,26)$, the effect of Gd on TH-mediated gene expression has not yet been studied. Second, several brain phenotypes caused by Gd exposure are similar to those of hypothyroid animals; however, the mechanism of Gd toxicity in the brain remains unclear. Moreover, the effects of Gd exposure on TR-mediated transcription and TH-mediated brain development have not yet been studied.

Here, we examined the effect of Gd on TR activity and TH-mediated brain development in vitro. We employed three different $\mathrm{Gd}$ compounds: $\mathrm{Gd}$ chloride $\left(\mathrm{GdCl}_{3}\right)$ as a free $\mathrm{Gd}^{3+}$ source, Gd-DTPA-BMA (Omniscan ${ }^{\mathrm{TM}}$ ) as a linear $\mathrm{Gd}$, and 
Gd-DOTA [Dotarem ${ }^{\mathrm{TM}}$ (Magnescope ${ }^{\mathrm{TM}}$ )] as a macrocyclic Gd. We examined the effects of these Gd compounds on cell viability and TR-mediated transcription using CV-1 cells. We also cultured newborn rat cerebellar tissue with Gd compounds to investigate their effect on TH-induced morphological changes in Purkinje cells because this is considered to be a good model for the study of TH action on neuronal morphogenesis and its modification by various chemicals and because the dendrite growth of Purkinje cells provides a reliable index of their function and development (27). Using this model, we found that Gd compounds altered dendritogenesis.

\section{MATERIALS AND METHODS}

\section{Chemicals}

Gd chloride $\left(\mathrm{GdCl}_{3}\right)$ hexahydrate (MW 371.70), with $99.9 \%$ purity and dissolved in distilled water, was purchased from Sigma (St. Louis, MO, USA) and stored in $-20^{\circ} \mathrm{C}$ until use. Gd-DTPA-BMA $\left(\right.$ Omniscan $\left.^{\mathrm{TM}}\right)$ and Gd-DOTA [Dotarem ${ }^{\mathrm{TM}}$ (Magnescope $\left.^{\mathrm{TM}}\right)$ ] were obtained from their respective manufacturers, and then diluted with distilled water to their final concentrations (Figure 1A). $\mathrm{T}_{3}$ (98\% purity) (Sigma) was diluted using a vehicle (final concentration of $0.04 \mathrm{NaOH}$ for $10^{-3} \mathrm{M}$ of $\mathrm{T}_{3}$ stock) as the diluent. $\mathrm{T}_{4}$ (98\% purity), purchased from Sigma, was diluted with DMSO (for $10^{-1} \mathrm{M}$ of $\mathrm{T}_{4}$ stock), and then diluted with DMEM/F12 to its final concentration from $10^{-1} \mathrm{M}$.

\section{Plasmids}

Expression vectors for rat $\operatorname{TR} \alpha 1$ and $\operatorname{TR} \beta 1$ have previously been described $(29,30)$. The luciferase (LUC) reporter constructs, artificial direct repeat TRE, DR4 to TK-LUC (DR4-TRE), and chick lysozyme (F2)-thymidine kinase (TK)-LUC (F2-TRE) have also been described elsewhere (30).

\section{Clonal Cell Culture}

Monkey kidney fibroblast-derived CV-1 clonal cells were maintained in DMEM (Sigma), supplemented with $10 \%$ fetal bovine serum deprived of small lipophilic hormone, with $100 \mathrm{U} / \mathrm{mL}$ penicillin and $100 \mu \mathrm{g} / \mathrm{mL}$ streptomycin (Invitrogen, San Diego, $\mathrm{CA}, \mathrm{USA}$ ) at $37^{\circ} \mathrm{C}$ under a $5 \% \mathrm{CO}_{2}$ atmosphere. The serum was stripped of hormones by constant mixing with 5\% (w/v) AGX1-8 resin (Bio-Rad, Hercules, CA, USA) and powdered charcoal before ultrafiltration (31).

\section{Analysis of Gd Deposition by Inductively Coupled Plasma-Mass Spectrometry}

Cells were plated at a density of $1 \times 10^{5}$ cells $/ \mathrm{mL}$ in six-well plates until $80 \%$ confluency was achieved and were incubated in the presence of Gd-DTPA-BMA, Gd-DOTA, or $\mathrm{GdCl}_{3}$ for $24 \mathrm{~h}$. After exposure, the cells were washed with phosphate buffered saline (PBS), and $500 \mu \mathrm{L}$ of $0.25 \mathrm{w} / \mathrm{v} \%$ Trypsin-1 mmol/L EDTA $4 \mathrm{Na}$ solution (Wako Pure Chemical Industries, Ltd., Tokyo, Japan) was added before they were scraped, centrifuged at $3000 \mathrm{rpm}$ for $3 \mathrm{~min}$, and washed again with PBS three times. The cell lysate was stored at $-80^{\circ} \mathrm{C}$ until used for inductively coupled plasma-mass spectrometer (ICP-MS) measurements.
Each homogenized sample was weighed and sealed in a perfluoroalkoxy vial along with $0.5 \mathrm{~mL}$ of nitric acid and $0.1 \mathrm{~mL}$ of hydrogen peroxide (Ultrapure reagent, Kanto Chemical, Tokyo, Japan) for hazardous metal analysis, and it was then subjected to sample digestion with eight sequences of a microwave program for 125 min with the MLS 1200 Mega (Milestone Inc., Shelton, CT, USA), which is a high performance microwave digestion unit. After cooling, it was diluted to $10 \mathrm{~mL}$ with ultrapure water. The total concentration of $\mathrm{Gd}^{3+}$ (free + bound) in the cells was measured with ICP-MS (ELAN DRC II ${ }^{\circledR}$ mass spectrometer, Perkin Elmer Life and Analytical Sciences Inc., Waltham, MA, USA) with the following parameters: ICP RF (radiofrequency) power, $1500 \mathrm{~W}$; plasma gas flow, $17.0 \mathrm{~L} / \mathrm{min}$; auxiliary gas flow, $1.20 \mathrm{~L} / \mathrm{min}$; and nebulizer gas flow, $0.86 \mathrm{~L} / \mathrm{min}$. A standard curve of inorganic $\mathrm{Gd}^{3+}(0-300 \mathrm{ppm})$ in $3 \% \mathrm{HNO}_{3}$ and digested sample solution was monitored by the responses of the stable isotopes ${ }^{158} \mathrm{Gd}$ and ${ }^{160} \mathrm{Gd}$. The cellular $\mathrm{Gd}$ concentration was determined by multiplying the weight of Gd per milliliter in the digested solution by the dilution factor and dividing it by the weight of the cellular sample.

\section{Cell Viability Assay}

We performed the 3-[4,5-dimethylthiazol-2-yl]-5-[3-carboxy methoxyphenyl]-2-[4-sulfophenyl]-2Htetrazolium (MTS) cell proliferation assay, as described in the instruction manual of the Promega Technical Bulletin CellTiter 96 ${ }^{\circledR}$ AQueous One Solution Cell Proliferation Assay. The conversion of MTS into aqueous soluble formazan was caused by the succinic dehydrogenase found in the metabolically active mitochondria. Cells were plated at a density of $1 \times 10^{5}$ cells $/ 0.1 \mathrm{~mL}$ in 96 -well plates until $80 \%$ confluency and were then incubated in the presence of Gd-DTPA-BMA, Gd-DOTA, or $\mathrm{GdCl}_{3}$, each for 24, 48, and 96 h, respectively. After exposure to these compounds, the MTS reagent was added to the medium. The absorbance, representing mitochondrial metabolic activity, was measured at $490 \mathrm{~nm}$ using a micro-plate reader (Bio-Rad). Relative values were calculated as percentages of the values obtained from the normal control group. All MTS studies were repeated at least three times in triplicate. Data are presented as means \pm SEM of one representative experiment performed in triplicate.

\section{Transient Transfection-Based Reporter Gene Assay}

Cells were plated at a density of $1 \times 10^{5}$ cells $/ \mathrm{mL}$ in 24 -well plates until $80 \%$ confluency, and then transfected using a calcium-phosphate precipitation method (31). Expression vectors encoding TR $(0.02 \mu \mathrm{g})$ were cotransfected with reporter (F2-TRE-LUC) $(0.2 \mu \mathrm{g})$ into $\mathrm{CV}-1$ cells. Cytomegalovirus- $\beta$ galactosidase plasmid $(0.04 \mu \mathrm{g})$ was cotransfected as the internal control. At $16-18 \mathrm{~h}$ after transfection, cells were incubated with stripped medium, containing the indicated concentration of a vehicle (final concentration of $0.04 \mathrm{M} \mathrm{NaOH}$ ) or ligand $\left(10^{-7} \mathrm{M} \mathrm{T}_{3}\right)$, and Gd-DTPA-BMA, Gd-DOTA, or $\mathrm{GdCl}_{3}$ for $24 \mathrm{~h}$. Cells were then harvested to measure the luciferase activity, as described elsewhere (31). Total amounts of DNA (0.26 $\mu \mathrm{g})$ per well were balanced by adding pcDNA3 plasmids (Invitrogen). 
A

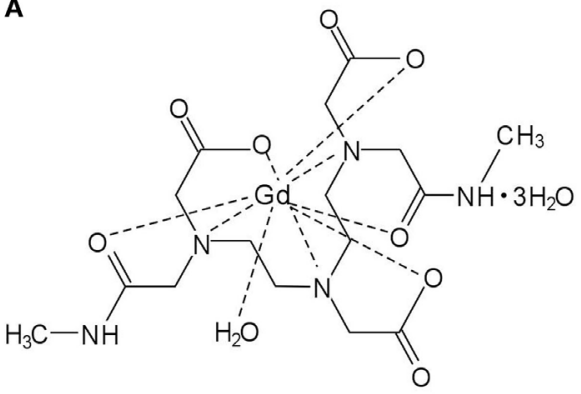

B<smiles>O=C([O-])CN1CCN(CC(=O)[O-])CCN(CC(=O)NC[C@H](O)[C@@H](O)[C@H](O)[C@H](O)[C@H](O)CO)CCN(CC(=O)O)CC1</smiles>

C $\quad\left(\times 10^{-7}\right)$

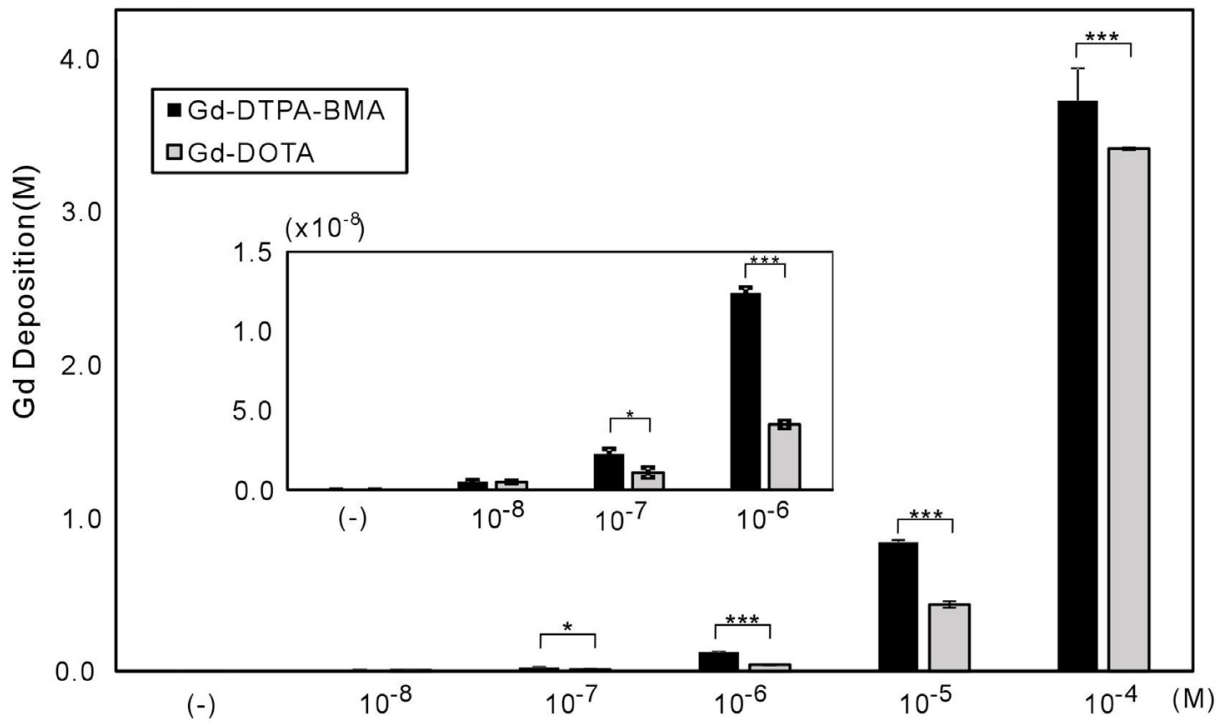

D $\quad\left(\times 10^{-5}\right)$

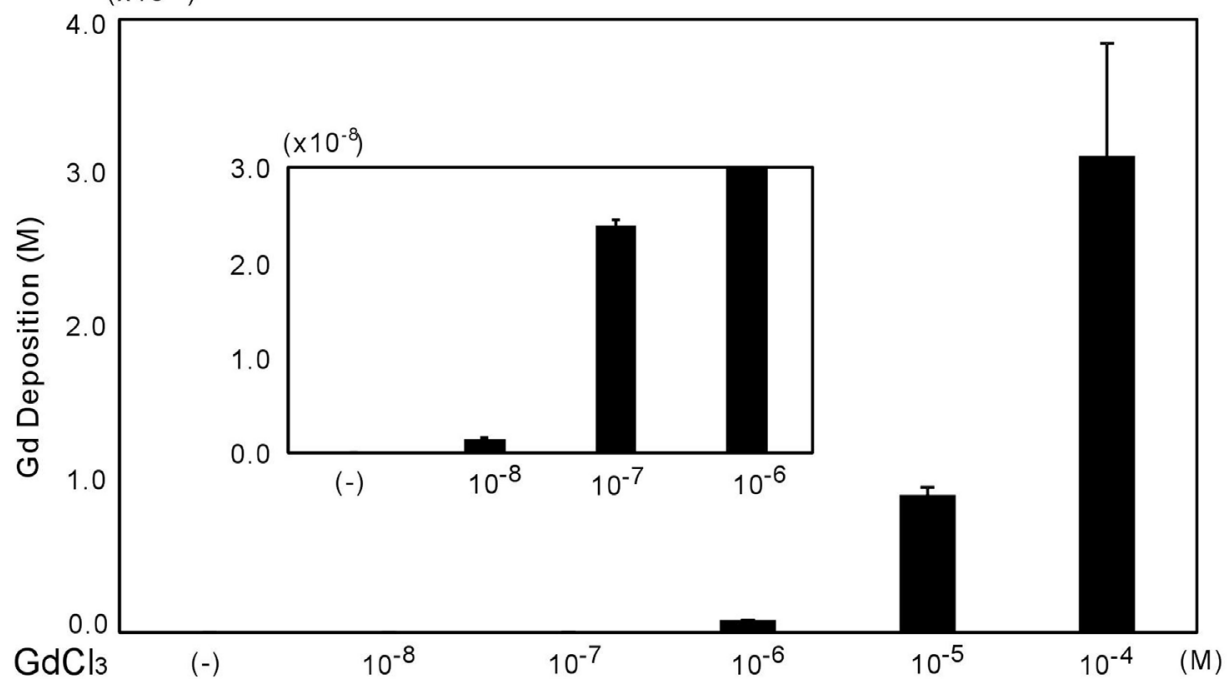

FIGURE 1 | Chemical structures of Gd-DTPA-BMA (A) and Gd-DOTA (B), with gadolinium deposition shown in CV-1 cells (C,D). (A,B) molecular structures of Gd-DTPA-BMA and Gd-DOTA, respectively (28). The CV-1 cells were exposed to $10^{-8}$ to $10^{-4} \mathrm{M}$ of Gd-DTPA-BMA, Gd-DOTA, or GdCl for $24 \mathrm{~h}$. The deposition of total gadolinium was determined by ICP-MS. Cellular Gd deposition (M/well) can be observed after Gd-DTPA-BMA and Gd-DOTA (C), and GdCl 3 treatment (D). Note that the gadolinium concentration after $\mathrm{GdCl}_{3}$ treatment was approximately 100 times higher than that after GBCA treatments. Data are presented as means \pm SEM of experiments performed in triplicate. ${ }^{* \star *} p<0.001$ and ${ }^{*} p<0.05$ indicate statistical significance by Bonferroni's test. 
LUC activities were normalized to $\beta$-galactosidase activity and then calculated as relative LUC activities. All transfection studies were repeated at least three times in triplicate. Data shown represent mean \pm SEM of one representative experiment performed in triplicate.

\section{Primary Cerebellar Culture}

A pregnant Wistar rat was purchased from Japan SLC (Hamamatsu, Japan), and newborn rats were euthanized under isoflurane anesthesia on the first day of birth. The animal experiment protocol in the present study was approved by the Animal Care and Experimentation Committee, Gunma University, and all efforts were made to minimize the number of animals used and their suffering. Details of the culture methods have been previously described (32). Briefly, cerebellar tissue was digested with $0.2 \mathrm{U} / \mathrm{mL}$ of papain (Worthington, Lakewood, NJ, USA) in PBS containing $0.2 \mathrm{mg} / \mathrm{mL}$ L-cysteine, $0.2 \mathrm{mg} / \mathrm{mL}$ bovine serum albumin (Intergen Company, Purchase, NY, USA), $5 \mathrm{mg} /$ $\mathrm{mL}$ glucose, and $0.02 \mathrm{mg} / \mathrm{mL}$ DNase I (Sigma, 400-600 U/mg). This was continued for $25 \mathrm{~min}$ with continued shaking at $36.5^{\circ} \mathrm{C}$. Dissociated cells were suspended in serum-free medium without THs and plated at a density of $3 \times 10^{5}$ cells $/ 0.3 \mathrm{~mL}$ in the wells of chamber slides (Lab-Tek 8-mm-diameter wells, Nalge Nunc International, Rochester, NY, USA) pre-coated with $0.1 \mathrm{mg} / \mathrm{mL}$ poly-L-lysine (Sigma). Then, at $16-24 \mathrm{~h}$ after plating, $\mathrm{T}_{4}\left(10^{-9} \mathrm{M}\right)$ or $\mathrm{T}_{3}\left(10^{-9} \mathrm{M}\right)$, and/or Gd-DTPA-BMA, Gd-DOTA, and $\mathrm{GdCl}_{3}$ were added to the culture medium. One half of the medium was replaced with fresh medium every 3 days, and the mixed cerebellar cells were cultured in a $5 \% \mathrm{CO}_{2}$ incubator at $37^{\circ} \mathrm{C}$ for 17 days. The effect of dimethyl sulfoxide was excluded using control and experimental media at a final concentration of $0.01 \%$, and by avoiding freezing and thawing.

\section{Immunocytochemistry for Calbindin to Analyze Purkinje Cell Development}

Immunocytochemistry of the cultured cells was performed, as previously described (32). Briefly, the Purkinje cells underwent immunochemical staining with a mouse monoclonal anticalbindin-28K antibody (1:200 Sigma) and a donkey anti-mouse $\operatorname{IgG}(\mathrm{H}+\mathrm{L})$ secondary antibody, Alexa Fluor $^{\circledR} 488$ conjugate (1:200; Thermo Fisher Scientific Inc., Waltham, MA, USA), and were then inspected under a laser confocal scanning microscope (FV1000D spectral type inverted Microscope IX81, Olympus, Tokyo, Japan, and ZEISS LSM 880, Carl Zeiss Microscopy GmbH, Jena, Germany). In some cultures, the cell nuclei were also stained with 4',6-diamidino-2-phenylindole (DAPI). To quantify dendrite arborization, the total area covered by the dendritic tree on 15 randomly selected Purkinje cells per experiment was determined by tracing the outline of the cell and its dendritic branches, before computing the total area using ImageJ software (NIH). The numbers of Purkinje cells (calbindin-positive cells) and DAPI-positive nuclei per well $\left(1 \mathrm{~cm}^{2}\right)$ were also counted. Data are presented as means \pm SEM, and the typical result from one experiment is shown graphically. More than three independent experiments were performed, and the results were consistent for each experiment.

\section{Statistical Analysis}

Treatment-related effects were analyzed using analysis of variance. Post hoc comparison was made using Bonferroni's test. All $p$-values $<0.05$ were considered to be statistically significant.

\section{RESULTS}

\section{Gadolinium Deposition in CV-1 Cells}

Gadolinium concentration in CV-1 cells after $24 \mathrm{~h}$ of exposure was measured by ICP-MS (Figure 1B). Gd-DTPA-BMA exposure $\left(10^{-8}\right.$ to $\left.10^{-4} \mathrm{M}\right)$ induced $\mathrm{Gd}$ accumulation in $\mathrm{CV}-1$ cells, ranging from $3 \times 10^{-10}$ to $4 \times 10^{-7} \mathrm{M}$. Although Gd-DOTA also induced $\mathrm{Gd}$ accumulation at the same dose ranges, the level of Gd deposition was significantly lower than that induced by Gd-DTPABMA. As a positive control, we also measured Gd deposition after $\mathrm{GdCl}_{3}$ treatment. In solution, $\mathrm{Gd}^{3+}$ freely dissociates from $\mathrm{Cl}^{-}$, and consistent with this, the levels of Gd were approximately 100 times greater than those after GBCA treatment (Figures 1C,D). However, it should be noted that we observed many precipitates in the culture medium when the $\mathrm{GdCl}_{3}$ concentration exceeded $10^{-7} \mathrm{M}$. This is consistent with previous studies showing that $\mathrm{Gd}$ may be precipitated as Gd phosphate or may promote precipitation of calcium-phosphate $(10,33)$.

\section{Effects of GBCA Exposure on Cell Viability}

The effects of Gd-DTPA-BMA, Gd-DOTA, and $\mathrm{GdCl}_{3}$ exposure on the viability of CV-1 cells were examined by MTS cell proliferation assay. Gd-DTPA-BMA and Gd-DOTA exposure did not affect cell viability (Figures 2A,B). By contrast, $\mathrm{GdCl}_{3}$ reduced cell viability by $60 \%$ at $24 \mathrm{~h}, 29 \%$ for $48 \mathrm{~h}$, and $20 \%$ at $96 \mathrm{~h}$ at a level of $10^{-4} \mathrm{M}$ (Figure 2C). These results indicate that GBCA exposure does not induce CV-1 cell death.

\section{Alteration of TR-Mediated Transcription Induced by Gd-DTPA-BMA}

We performed transient transfection-based reporter gene assay in CV-1 cells to investigate the effect of Gd-DTPA-BMA, Gd-DOTA, and $\mathrm{GdCl}_{3}$ on TR-mediated transcription (Figure 3). In the presence of $\mathrm{T}_{3}\left(10^{-7} \mathrm{M}\right)$, lower doses of Gd-DTPA-BMA $\left(10^{-8}\right.$ to $\left.10^{-6} \mathrm{M}\right)$ augmented $\mathrm{TR} \beta 1$-mediated transcription through F2-TRE, whereas transcription was suppressed by higher doses of Gd-DTPA-BMA $\left(10^{-5}\right.$ to $\left.10^{-4} \mathrm{M}\right)$ (Figure 3A). However, exposure to Gd-DOTA did not change the TR $\beta 1$ mediated transcription through F2-TRE in the presence of $\mathrm{T}_{3}$ at the same level $\left(10^{-7} \mathrm{M}\right)$ (Figure 3B). Suppression of transcription was also caused by high-dose $\mathrm{GdCl}_{3}$ (Figure 3C). We also performed similar analyses using TR $\alpha$ instead of $\operatorname{TR} \beta$ and using DR4-TRE instead of F2-TRE. The effect was essentially the same, even when we changed the TR-TRE combination (data not shown). When we carefully examined the changes in $\beta$-galactosidase activities (Figures 3D-F) to evaluate the change in cellular function, we found that after Gd-DTPA-BMA treatment, $\beta$-galactosidase activity tended to decline with increase in its concentration (Figure 3D). Thus, the decline in transcription that was observed with higher doses of Gd-DTPA-BMA may not be due to direct inhibition of TR-mediated transcription but 


\section{A Gd-DTPA-BMA}

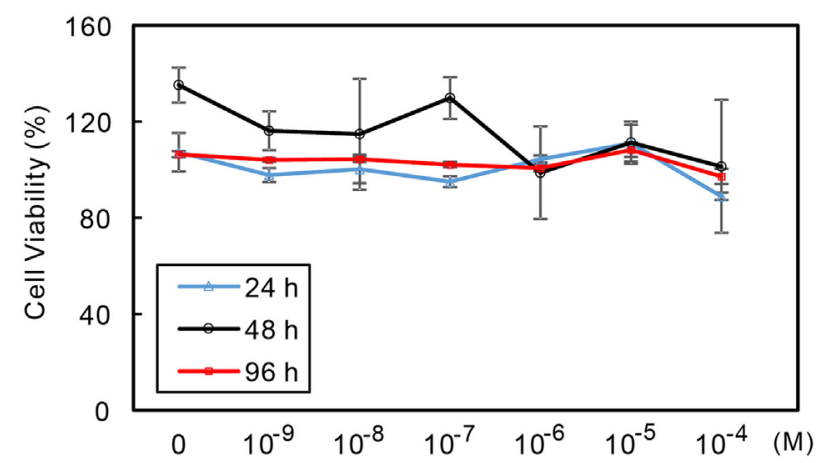

B Gd-DOTA

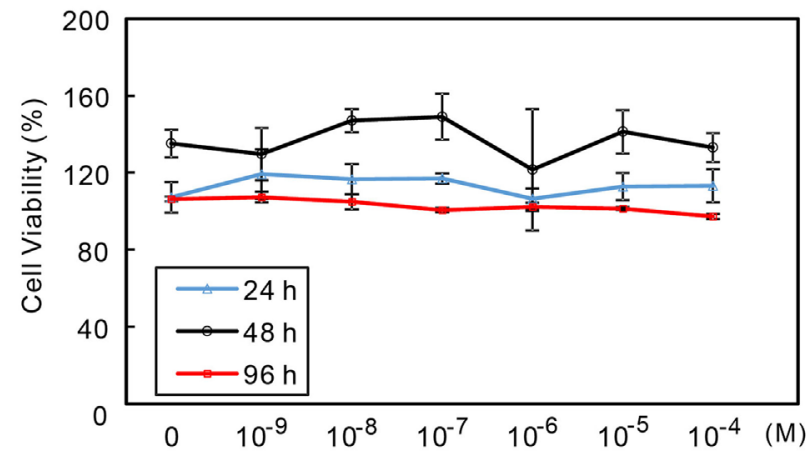

c $\mathrm{GdCl}_{3}$

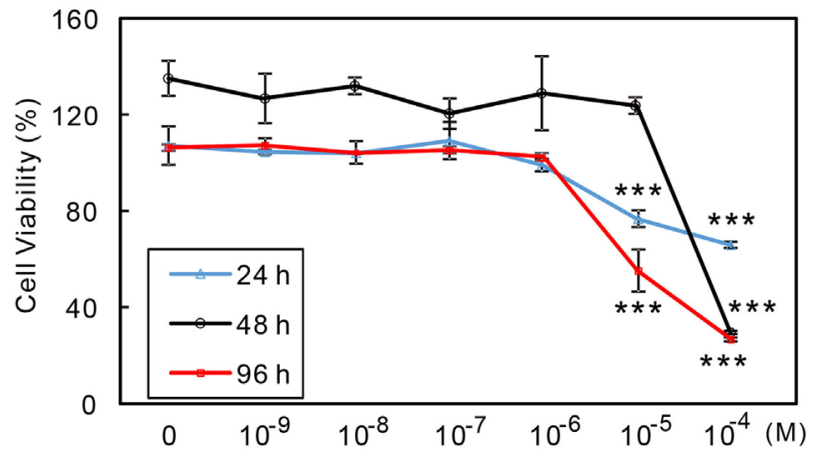

FIGURE 2 | Effects of GBCA or $\mathrm{GdCl}_{3}$ exposure on the cellular viability. CV-1 cells were exposed to several concentrations of Gd-DTPA-BMA (A), Gd-DOTA (B), and $\mathrm{GdCl}_{3}$ (C), each for 24, 48, and 96 h, respectively. Cell viability was determined by MTS assay and calculated as a percentage of the control viability. Data are presented as means \pm SEM of experiments performed in triplicate. ${ }^{* \star *} p<0.001$ indicates statistical significance by Bonferroni's test compared with the negative control (no Gd treatment).

rather by inhibition of cellular function. During treatment with $\mathrm{GdCl}_{3}, \beta$-galactosidase activity was significantly decreased as the concentration increased, indicating that $\mathrm{Gd}^{3+}$ disrupted cellular function (Figure 3F). In the groups treated with Gd-DOTA, $\beta$-galactosidase activity was not altered (Figure 3E), regardless of the dose, indicating that Gd-DOTA did not affect TR-mediated transcription.

\section{Exposure to Gd Compounds Impaired the TH-Dependent Dendrite Arborization of Purkinje Cells and Induced Purkinje Cell Death in Primary Cerebellar Culture}

The results using CV-1 cells showed that Gd may partly disrupt $\mathrm{TH}$ action and cause adverse effects. Consequently, we examined the effect of Gd-DTPA-BMA, Gd-DOTA, and $\mathrm{GdCl}_{3}$ exposure on TH-mediated Purkinje cell development in a culture of newborn rat cerebellar tissue. The cerebellar cells of newborn pups were cultured with $\mathrm{TH}$ and/or Gd compounds for 17 days and then stained with anti-calbindin-28K antibody and DAPI (Figures 4 and 5). In the $\mathrm{T}_{4}$-treated cultures, the cells were distributed evenly in the plate (Figure 4), whereas in $\mathrm{T}_{3}$-treated cultures, the cells tended to aggregate in the plate (Figure 5). These results are consistent with previous study (34). Purkinje cells were located within such cellular aggregates in $\mathrm{T}_{3}$-treated cultures. $\mathrm{T}_{4}$ or $\mathrm{T}_{3}$ treatment markedly promoted the dendrite arborization of Purkinje cells. Exposure to $10^{-7} \mathrm{M}$ Gd-DTPA-BMA significantly augmented the $10^{-9} \mathrm{M} \mathrm{T}_{4}$-induced arborization, whereas higher doses of Gd-DTPA-BMA $\left(10^{-5} \mathrm{M}\right)$ dramatically inhibited it (Figure 4A). By contrast, when $10^{-9} \mathrm{M}$ $\mathrm{T}_{3}$ was used, Gd-DTPA-BMA $\left(10^{-7} \mathrm{M}\right)$ did not augment the dendrite arborization (Figure 5A), probably because $\mathrm{T}_{3}$-induced dendrite arborization was much greater than for $\mathrm{T}_{4}$. On the other hand, $10^{-5} \mathrm{M}$ Gd-DTPA-BMA significantly inhibited the $\mathrm{T}_{3}$-induced dendrite arborization. Gd-DOTA did not affect $\mathrm{T}_{4}$ induced dendrite arborization (Figure 4A), whereas $\mathrm{T}_{3}$-induced dendrite arborization was weakly suppressed by high doses of Gd-DOTA (Figure 5A). $\mathrm{GdCl}_{3}$ with $\mathrm{T}_{4}$ or $\mathrm{T}_{3}$ treatment markedly suppressed the arborization, even at a dose of $10^{-7} \mathrm{M}$. In $\mathrm{T}_{4}$-treated cultures, the number of Purkinje cells decreased with high doses of Gd-DTPA-BMA or any doses of $\mathrm{GdCl}_{3}$ (Figure 4C). In $\mathrm{T}_{3}$-treated cultures, on the other hand, treatment of all $\mathrm{Gd}$ compounds decreased the number of Purkinje cells (Figure 5C). The potency to decrease the number was $\mathrm{GdCl}_{3}>\mathrm{Gd}$-DTPABMA > Gd-DOTA. Furthermore, in $\mathrm{T}_{4}$-treated cultures, $10^{-5} \mathrm{M}$ $\mathrm{GdCl}_{3}$ reduced the total number of cells (Figure 4D), whereas in $\mathrm{T}_{3}$-treated cultures, $10^{-5} \mathrm{M}$ Gd-DTPA-BMA or $\mathrm{GdCl}_{3}$ treatment reduced the total number of cells (Figure 5D).

\section{DISCUSSION}

Here, we initially hypothesized that GBCAs may accumulate in cells and cause adverse effects by disrupting TH action in the brain. Consequently, we studied the effects of GBCA on cellular Gd concentration, TR-mediated transcription, and TH-mediated arborization of cultured Purkinje cell dendrites. We showed that Gd accumulated in CV-1 cells after GBCA and $\mathrm{GdCl}_{3}$ treatment for $24 \mathrm{~h}$. Although TR-mediated transcription and $\mathrm{T}_{4}$-mediated Purkinje cell dendrite arborization were augmented by low-dose Gd-DTPA-BMA but suppressed by high-dose of Gd-DTPABMA, Gd-DOTA at comparable levels did not alter $\mathrm{T}_{4}$-mediated dendrite arborization. On the other hand, $\mathrm{T}_{3}$ induced greater arborization than $\mathrm{T}_{4}$. Under such circumstances, the low-dose Gd-DTPA-BMA-induced augmentation seen with $\mathrm{T}_{4}$ was not detected, whereas high doses of Gd-DTPA-BMA suppressed 

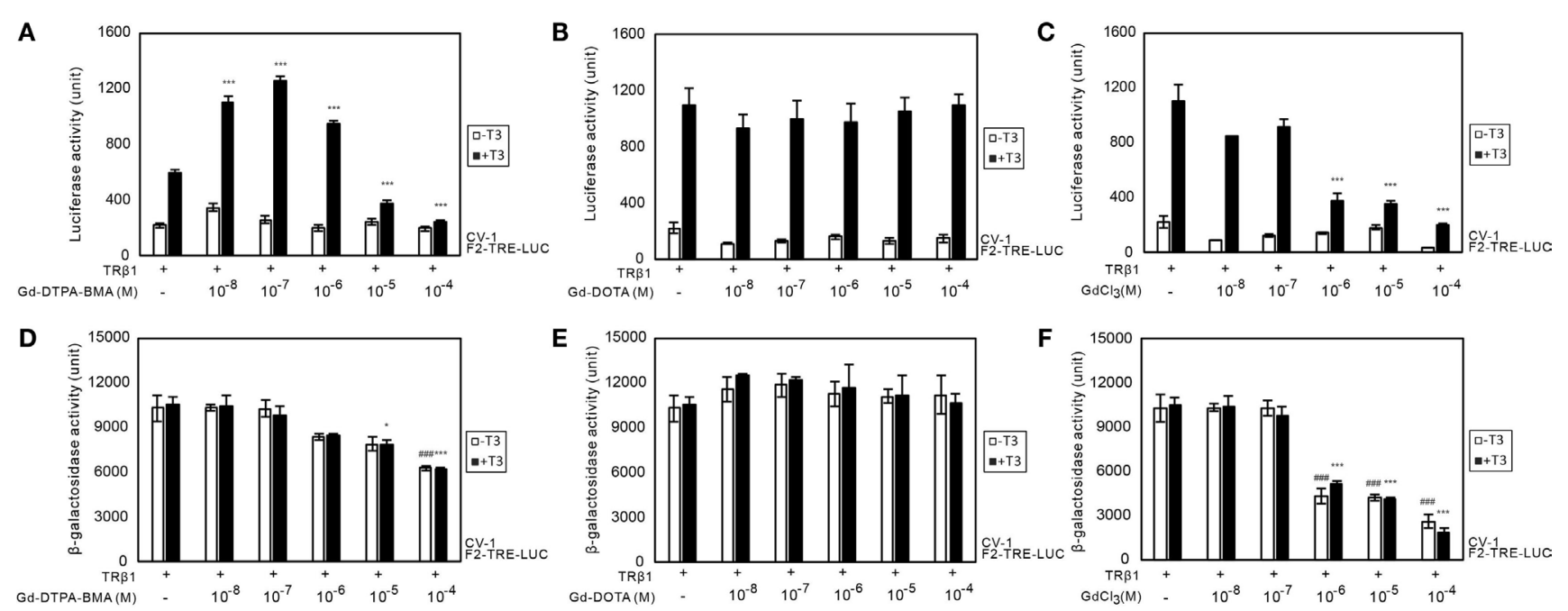

FIGURE 3 | Effects of GBCA or $\mathbf{G d C l}_{3}$ on TR-mediated transcription. Expression plasmids encoding TR $\beta 1$ were cotransfected with F2-TK-LUC into CV-1 cells. Cells were cultured with or without $10^{-7} T_{3}$ and the indicated amount of Gd-DTPA-BMA (A,D), Gd-DOTA (B,E), or GdCl 3 (C,F). To compare the general cellular transcriptional activity, luciferase and $\beta$-galactosidase activities in the cell lysate after Gd-DTPA-BMA (A,D), Gd-DOTA (B,E), or GdCl 3 (C,F) treatment are shown. The total amount of DNA per well was balanced by adding a pcDNA3 vector. Data are presented as means \pm SEM of experiments performed in triplicate. ${ }^{\star \star *} p<0.001,{ }^{\star \star} p<0.01$, and ${ }^{\star} p<0.05$ indicate statistical significance by Bonferroni's test compared with TR $\beta 1$ ( + ), $T_{3}$ ( + ), and Gd-DTPA-BMA, Gd-DOTA, or $\mathrm{GdCl}_{3}(-)$. ${ }^{\# \#} p<0.001$ indicates statistical significance by Bonferroni's test compared with TR $\beta 1$ (+), $\mathrm{T}_{3}(-)$, and Gd-DTPABMA, Gd-DOTA, or $\mathrm{GdCl}_{3}(-)$.

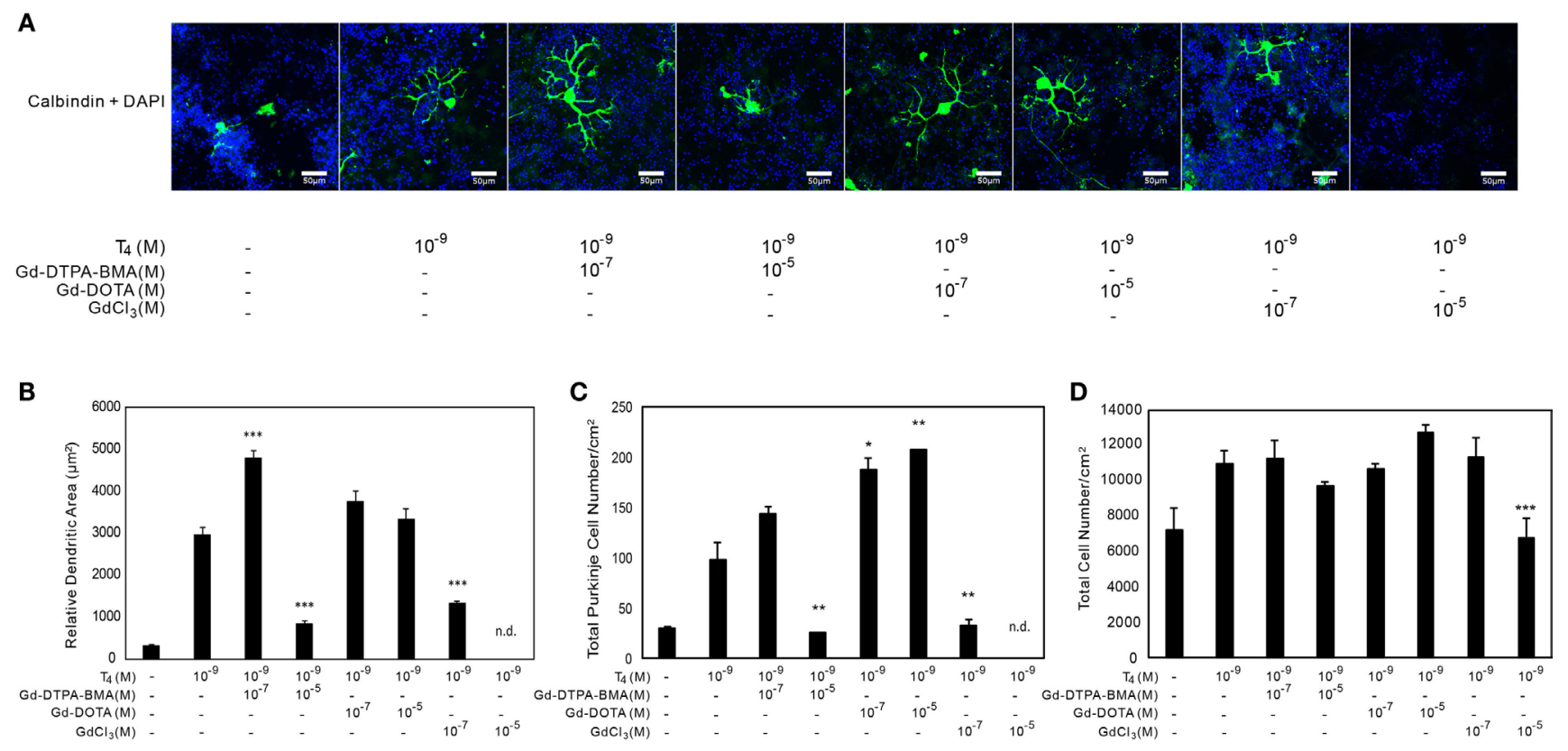

FIGURE 4 | Effects of GBCA or $\mathrm{GdCl}_{3}$ on the $\mathrm{T}_{4}$-induced arborization of Purkinje cell dendrites and the relative number of Purkinje cells. Cerebellar cells were cultured for 17 days followed by immunohistochemical analysis with calbindin and DAPI. (A) Representative photomicrographs showing the effects of Gd-DTPA-BMA, Gd-DOTA, or $\mathrm{GdCl}_{3}$ on Purkinje cell morphology. Bars indicate $50 \mu \mathrm{m}$. (B) Change in the dendritic areas of Purkinje cells following Gd-DTPA-BMA, Gd-DOTA, or $\mathrm{GdCl}_{3}$ treatment. (C) Change in the number of Purkinje cells/well $\left(1 \mathrm{~cm}^{2}\right)$ following Gd-DTPA-BMA, Gd-DOTA, or GdCl 3 treatment. (D) Total number of DAPI-positive nuclei/well $\left(1 \mathrm{~cm}^{2}\right)$ following Gd-DTPA-BMA, Gd-DOTA, or $\mathrm{GdCl}_{3}$ treatment. Dendritic areas and total number of DAPI-positive nuclei were quantified using ImageJ software $(\mathrm{NIH})$, and the total number of Purkinje and total cells/well was manually counted. Data are expressed as means \pm SEM $(n=15$ determinations) and are representative of at least three independent experiments. ${ }^{\star \star \star} p<0.001,{ }^{\star \star} p<0.01$, and ${ }^{*} p<0.05$ indicate statistical significance by Bonferroni's test compared with $\mathrm{T}_{4}(+)$, and Gd-DTPA-BMA, Gd-DOTA, or GdCl 3 (-). 


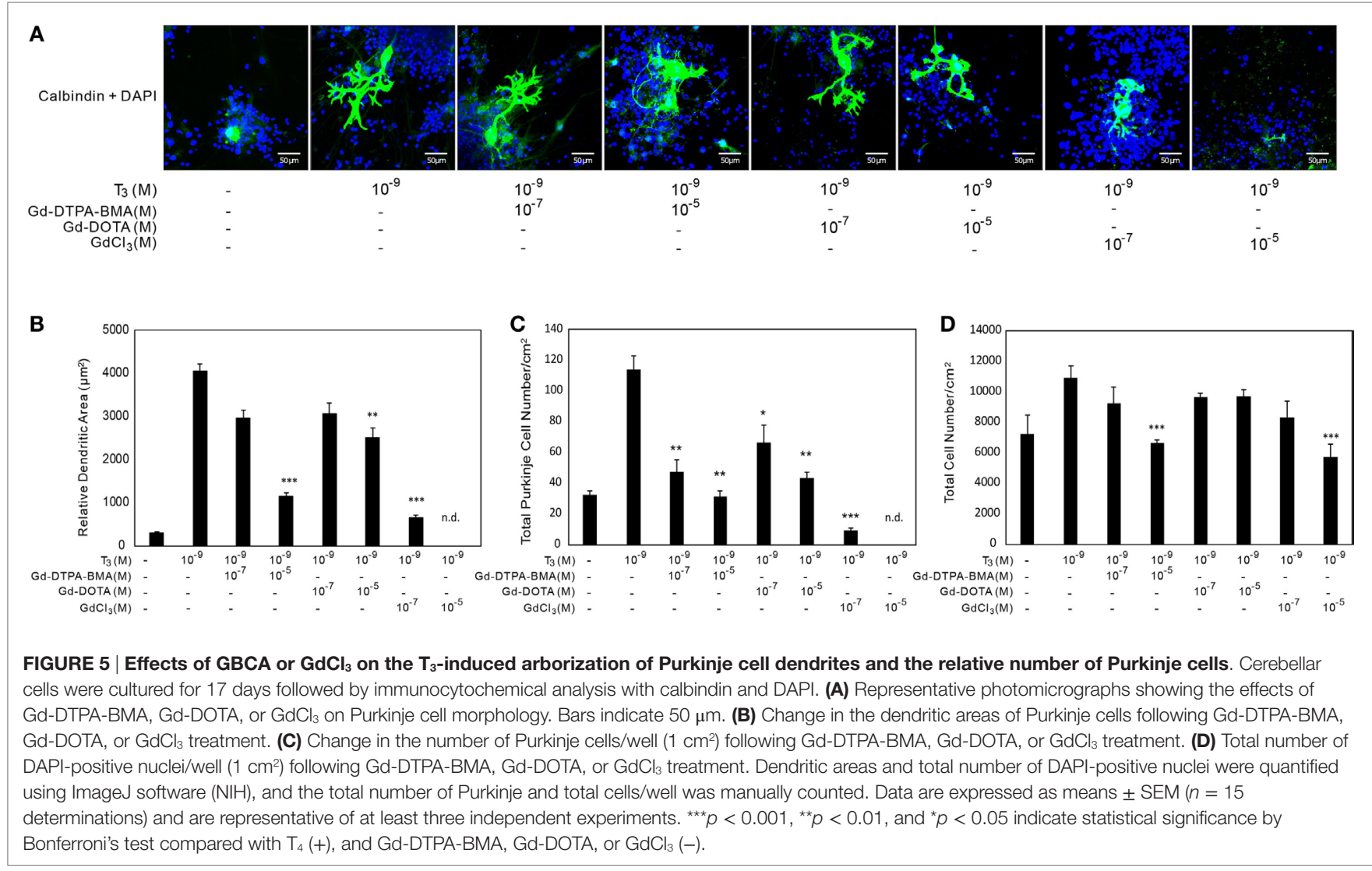

$\mathrm{T}_{3}$-mediated Purkinje cell dendrite arborization. On the other hand, $\mathrm{GdCl}_{3}$ suppressed cellular function, as evidenced by suppressed $\beta$-galactosidase activity and its marked suppression of TH-mediated dendrite arborization in primary cultures. Furthermore, high-dose Gd-DTPA-BMA in $\mathrm{T}_{4}$-treated cultures and all GBCA compounds in $\mathrm{T}_{3}$-treated cultures significantly reduced the number of Purkinje cells. These results indicate that not only the Gd ion but also chelated Gd compounds may adversely affect the brain by disrupting $\mathrm{TH}$ action.

Another interesting finding of the present study is the difference of GBCA action in $\mathrm{T}_{4^{-}}$and $\mathrm{T}_{3}$-treated cultures. As stated above, the cellular distribution in cultures differed between these two treatments in that cells were more aggregated in the $\mathrm{T}_{3^{-}}$ treated cultures. A previous study has indicated that the reduced cellular migration in $\mathrm{T}_{3}$-treated cultures is due to disruption of integrin $\alpha 3 \beta 1$ and extracellular matrix interaction, which is activated by $T_{4}$ or reverse $T_{3}$, but not by $T_{3}$ (34). Purkinje cells were usually found in the regions where the cells were concentrated. Dendrite arborization was augmented by both TH treatments. $\mathrm{T}_{3}$ showed a greater effect $(1.33 \times)$ and this greater amount of arborization may have masked low-dose Gd-DTPABMA-induced augmentation of arborization seen in $\mathrm{T}_{4}$-treated cultures. On the other hand, while low-dose Gd-DTPA-BMA or any dose of Gd-DOTA did not alter the number of Purkinje cell in $\mathrm{T}_{4}$-treated cultures (Figure 4C), all Gd compounds reduced the number of Purkinje cells in the $\mathrm{T}_{3}$-treated cultures (Figure 5C). The effect of Gd compounds on the total number of cells was also greater in the $\mathrm{T}_{3}$-treated cultures. Although the exact reason for this difference remains unclear, a reduction of cell-to-cell interaction in $\mathrm{T}_{3}$-treated cultures may have enhanced the toxicity of the Gd compounds.

Here, although cellular Gd accumulation was much lower with GBCA treatment than with $\mathrm{GdCl}_{3}$ treatment, it was unclear whether GBCA itself or dissociated $\mathrm{Gd}^{3+}$ was deposited in the cells. A previous study demonstrated that although de-chelation and release of dissociated $\mathrm{Gd}^{3+}$ are observed in Gd-DTPA-BMA, the Gd-DOTA form is stable (35). This is consistent with our results, showing higher Gd accumulation with Gd-DTPA-BMA treatment than with Gd-DOTA treatment. Thus, we assume that most of the Gd deposition in this study was caused by dissociated $\mathrm{Gd}^{3+}$.

After dissociation, $\mathrm{Gd}^{3+}$ may bind to anions (phosphate, carbonate, and hydroxide) in the body fluid to form insoluble salts, which may be deposited in cells where they may cause adverse effects (33). The results of our study support this hypothesis because the level of toxicity (cell viability, $\beta$-galactosidase activity, and decrease in dendrite arborization) correlated with the magnitude of dissociation $\left(\mathrm{GdCl}_{3}>\right.$ Gd-DTPABMA > Gd-DOTA). However, at a concentration of $10^{-4} \mathrm{M}$, although Gd-DTPA-BMA and Gd-DOTA showed similar Gd accumulation, only Gd-DTPA-BMA suppressed TR-mediated transcription, decreased $\beta$-galactosidase expression, and decreased dendrite arborization. Additional mechanisms may be involved in causing such differences. 
It is necessary to resolve whether dissociated $\mathrm{Gd}^{3+}$ or GBCA enters the cell. As mentioned earlier, dissociated $\mathrm{Gd}^{3+}$ may bind to anions, such as phosphate, which can then precipitate, bind with the plasma membrane, and disrupt cellular function, such as blocking calcium channels. We could not find any previous study showing that extracellular Gd- or Gd-chelated compounds enter cells by endocytosis, channels, or transporters. Here, however, low-dose Gd-DTPA-BMA was shown to augment TR-mediated transcription without altering $\beta$-galactosidase activity, as well as $\mathrm{T}_{4}$-activated Purkinje cell dendritogenesis. Inhibition of the activity of nuclear TR suppresses dendritogenesis in Purkinje cells, and this process is mediated by THs (36). These results indicate that Gd-DTPA-BMA suppressed TH activity in the nuclei. Although the mechanism causing such a disruption is unclear, several possibilities can be considered.

The first possibility is that disruption of calcium signaling by Gd-DTPA-BMA may alter the action of TRs. TH-mediated transcription is partly regulated by $\mathrm{Ca}^{2+} /$ calmodulin-dependent protein kinase type IV (CaMKIV) (37), whose activity is triggered by $\mathrm{Ca}^{2+} /$ calmodulin binding. Disruption of intracellular $\mathrm{Ca}^{2+}$ homeostasis by blocking calcium channels with Gd-DTPA-BMA may alter CaMKIV activity, leading to alteration of TR-mediated transcription. Another possibility is the disruption of membrane receptor-mediated $\mathrm{TH}$ action. In addition to nuclear TR, THs, particularly $\mathrm{T}_{4}$, also bind to integrin $\alpha v \beta 3$ (38), which mediate various intracellular events through the protein kinase $\mathrm{C} /$ phospholipase $\mathrm{C}$ pathway. Previous studies indicate that this protein mediates the shuttling of both TR $\beta$ and TR $\alpha$ from the cytoplasm to the nucleus $(39,40)$. However, Gd-DTPA can be used for integrin $\alpha v \beta 3$ imaging (41). Integrin $\alpha v \beta 3$ is expressed in CV- 1 cells (42) and astrocytes (43), where it mediates TH action in Purkinje cells by the conversion of $\mathrm{T}_{4}$ to $\mathrm{T}_{3}$. Thus, our results are consistent with the hypothesis that Gd-DTPA-BMA may bind to integrin $\alpha v \beta 3$ and modulate TH action. However, it should be noted that although Gd-DTPA-BMA treatment showed a biphasic effect on TH activity (augmentation at low doses and suppression at high doses), the mechanism behind this probably depends on the dose, with the disruption of TR-mediated transcription at low doses and suppression of cellular function at higher doses. However, further experiments are required to clarify whether the disruption of TH-mediated action by Gd compounds are caused by disrupting the integrin $\alpha v \beta 3$ pathway in astrocytes or by disrupting TR action in Purkinje cells, or both.

Gd-based contrast agents are deposited in the skin, liver, kidney, lung, heart, spleen, diaphragm, and femoral muscle of rats $(5,6)$. Skin accumulation of GBCAs may cause NSF, particularly in patients with renal insufficiency $(9,44)$. This is relevant to this study because Gd deposition is also observed in the brain (11), and severe behavioral changes resulted from the administration of GBCA to rat brains (15). Administration of other lanthanides has also been associated with impaired learning and memory (16). Here, we also observed suppression of TH-induced dendritogenesis in the Purkinje cells. Together, these results indicate that the abnormal behavioral alteration following Gd administration may result, at least in part, from the disruption of $\mathrm{TH}$ activity in the brain; however, further study is needed to confirm the mechanism. Ishitobi et al. reported that perinatal exposure to Cd suppressed the mRNA expression of neurogranin (RC3), which is a TH-regulated gene that may play an important role in memory and learning (45). It is possible that such alteration of TH-mediated gene expression may cause adverse effects.

Chelated $\mathrm{Gd}$ in linear or macrocyclic forms was originally developed to reduce the toxic effects of free Gd. GBCAs are used as clinically approved MRI contrast agents, and a typical ligand used to create a MRI contrast agent has eight donor atoms (1). As discussed earlier, chelated Gd has different stabilities, with ionic-macrocyclic Gd-DOTA being the most stable and non-ionic linear chelates, i.e., gadodiamide (Gd-DTPA-BMA) and gadoversetamide, being the least stable (7). These different characteristics may be the reason for the different effects between Gd-DOTA and Gd-DTPA-BMA in the brain. Thus, appropriate use of GBCA is crucial to avoid adverse effects in the brain. Gd compounds have been found to be accumulated in biological and environmental samples, including surface waters near populated areas all over the world. GBCA application during MRI has been shown to elevate accumulation of Gd in the water surface (46). This is important because we showed that low-dose Gd-DTPA-BMA could alter TR-mediated transcription. Thus, more attention should be paid to environmental Gd pollution.

Therefore, GBCAs were deposited in CV-1 cells, but only Gd-DTPA-BMA altered TR-mediated transcription, with possible augmentation of TR action at low doses and inhibition of cellular function at high doses. Arborization of Purkinje cell dendrites was also altered by GBCAs in both $\mathrm{T}_{3^{-}}$and $\mathrm{T}_{4}$-treated cultures. Gd-DOTA showed weak suppression of dendrite arborization at high doses and decrease in the number of Purkinje cells only in $\mathrm{T}_{3}$-treated cultures, in which cell-to-cell interaction may not be as stable as those in $\mathrm{T}_{4}$-treated cultures. Thus, this compound was considered to be safer compared with Gd-DTPABMA. These results indicate that an appropriate GBCA should be used to avoid adverse effects. In addition, the possibility that Gd may act as an endocrine-disrupting chemical at low doses requires further attention.

\section{AUTHOR CONTRIBUTIONS}

WA, TI, and WM conducted the complete experiment and prepared the data and manuscript. YT and NK had responsibility for the whole experiment, earned the grant, made the strategy, and prepared the manuscript. EK and TN contributed by experimental support. SK and HK were responsible for the ICP-MS measurements.

\section{ACKNOWLEDGMENTS}

We thank Dr. Izuki Amano, Dr. Yusuke Takatsuru, Dr. Asahi Haijima, Mr. Hiroyuki Yajima, Mr. Michifumi Kokubo, and Ms. Miski Aghnia for their technical assistance and advice.

\section{FUNDING}

This work was supported by the JSPS KAKENHI Grant 25281024 (to NK) and NPO Asian Nuclear Medicine Forum (to WA). 


\section{REFERENCES}

1. Sherry AD, Caravan P, Lenkinski RE. A primer on gadolinium chemistry. J Magn Reson Imaging (2009) 30:1240-8. doi:10.1002/jmri.21966.A

2. Kanda T, Oba H, Toyoda K, Kitajima K. Brain gadolinium deposition after administration of gadolinium-based contrast agents. Jpn J Radiol (2015) 34(1):3-9. doi:10.1007/s11604-015-0503-5

3. Aime S, Caravan P. Biodistribution of gadolinium-based contrast agents, including gadolinium deposition. J Magn Reson Imaging (2009) 30:1259-67. doi:10.1002/jmri.21969.Biodistribution

4. White GW, Gibby WA, Tweedle MF. Comparison of Gd (DTPA-BMA) (Omniscan) versus retention in human bone tissue by inductively coupled plasma mass spectroscopy. Invest Radiol (2006) 41:272-8. doi:10.1097/01. rli.0000186569.32408.95

5. Sato T, Ito K, Tamada T, Kanki A, Watanabe S, Nishimura H, et al. Tissue gadolinium deposition in renally impaired rats exposed to different gadolinium-based MRI contrast agents: evaluation with inductively coupled plasma mass spectrometry (ICP-MS). Magn Reson Imaging (2013) 31:1412-7. doi:10.1016/j.mri.2013.03.025

6. Wáng YJ, Schroeder J, Siegmund H, Idée J, Fretellier N, Factor C, et al. Total gadolinium tissue deposition and skin structural findings following the administration of structurally different gadolinium chelates in healthy and ovariectomized female rats. Quant Imaging Med Surg (2015) 5:534-45. doi:10.3978/j.issn.2223-4292.2015.05.03

7. Morcos SK. Extracellular gadolinium contrast agents: differences in stability. Eur J Radiol (2008) 66:175-9. doi:10.1016/j.ejrad.2008.01.025

8. Wermuth PJ, Jimenez SA. Gadolinium compounds signaling through TLR 4 and TLR 7 in normal human macrophages: establishment of a proinflammatory phenotype and implications for the pathogenesis of nephrogenic systemic fibrosis. J Immunol (2012) 189:318-27. doi:10.4049/jimmunol. 1103099

9. Piera-Velazquez S, Louneva N, Fertala J, Wermuth PJ, Del Galdo F, Jimenez SA. Persistent activation of dermal fibroblasts from patients with gadolinium-associated nephrogenic systemic fibrosis. Ann Rheum Dis (2010) 69:2017-23. doi:10.1136/ard.2009.127761

10. Gou B, Bian S, Zhang T, Wang K. Gadolinium-promoted precipitation of calcium phosphate is associated with profibrotic activation of RAW 264.7 macrophages. Toxicol Vitr (2010) 24:1743-9. doi:10.1016/j.tiv.2010.05.004

11. Kanda T, Fukusato T, Matsuda M, Toyoda K, Oba H, Haruyama T, et al. Gadolinium-based contrast agent accumulates in the brain even in subjects without severe renal dysfunction: evaluation of autopsy brain specimens with inductively coupled plasma mass spectroscopy. Neuroradiology (2015) 276:228-32. doi:10.1148/radiol.2015142690

12. Kanda T, Osawa M, Oba H, Toyoda K, Kotoku J, Haruyama T, et al. High signal intensity in dentate nucleus on unenhanced T1-weighted MR images: association with linear versus macrocyclic gadolinium chelate administration. Radiology (2015) 275:803-9. doi:10.1148/radiol.14140364

13. Feng X, Xia Q, Yuan L, Yang X, Wang K. Impaired mitochondrial function and oxidative stress in rat cortical neurons: implications for gadolinium-induced neurotoxicity. Neurotoxicology (2010) 31:391-8. doi:10.1016/j. neuro.2010.04.003

14. Xia Q, Feng X, Huang H, Du L, Yang X, Wang K. Gadolinium-induced oxidative stress triggers endoplasmic reticulum stress in rat cortical neurons. J Neurochem (2011) 117:38-47. doi:10.1111/j.1471-4159.2010.07162.x

15. Toney GM, Chavez HA, Ibarra R, Jinkins JR. Acute and subacute physiological and histological studies of the central nervous system after intrathecal gadolinium injection in the anesthetized rat. Invest Radiol (2001) 36:33-40. doi:10.1097/00004424-200101000-00005

16. Briner W, Rycek RF, Moellenberndt A, Dannull K. Neurodevelopmental effects of lanthanum in mice. Neurotoxicol Teratol (2000) 22:573-81. doi:10.1016/ S0892-0362(00)00075-1

17. Koibuchi N, Chin WW. Thyroid hormone action and brain development. Trends Endocrinol Metab (2000) 11:123-8. doi:10.1016/S1043-2760(00) 00238-1

18. Koibuchi N. The role of thyroid hormone on cerebellar development. Cerebellum (2008) 7:530-3. doi:10.1007/s12311-008-0069-1

19. Bernal J. Thyroid hormones in brain development and function. Nat Clin Pract Endocrinol Metab (2007) 3:249-59. doi:10.1038/ncpendmet0424
20. Ahmed OM, El-Gareib AW, El-bakry AM, Abd El-Tawab SM, Ahmed RG. Thyroid hormones states and brain development interactions. Int J Dev Neurosci (2008) 26:147-209. doi:10.1016/j.ijdevneu.2007.09.011

21. Koibuchi $\mathrm{N}$. The role of thyroid hormone on functional organization in the cerebellum. Cerebellum (2013) 12:304-6. doi:10.1007/s12311-012-0437-8

22. Yen PM. Physiological and molecular basis of thyroid hormone action. Physiol Rev (2001) 81:1097-142.

23. Cheng SY, Leonard JL, Davis PJ. Molecular aspects of thyroid hormone actions. Endocr Rev (2010) 31:139-70. doi:10.1210/er.2009-0007

24. Brent GA. Mechanisms of thyroid hormone action. Sci Med (2012) 122: 3035-43. doi:10.1172/JCI60047.three

25. Chen A, Kim SS, Chung E, Dietrich KN. Thyroid hormones in relation to lead, mercury, and cadmium exposure in the national health and nutrition examination survey, 2007-2008. Environ Health Perspect (2013) 121:2007-8. doi:10.1289/ehp.1205239

26. Georgescu B, Georgescu C, Stelian D, Bouaru A, Pa S. Heavy metals acting as endocrine disrupters. Anim Sci Biotechnol (2011) 44:89-93.

27. Kimura-Kuroda J, Nagata I, Negishi-Kato M, Kuroda Y. Thyroid hormonedependent development of mouse cerebellar Purkinje cells in vitro. Dev Brain Res (2002) 137:55-65. doi:10.1016/S0165-3806(02)00408-X

28. Geraldes CFGC, Laurent S. Classification and basic properties of contrast agents for magnetic resonance imaging. Contrast Media Mol Imaging (2009) 4:1-23. doi:10.1002/cmmi.265

29. Iwasaki T, Chin WW, Ko L. Identification and characterization of RRMcontaining coactivator activator (CoAA) as TRBP-interacting protein, and its splice variant as a coactivator modulator (CoAM). J Biol Chem (2001) 276:33375-83. doi:10.1074/jbc.M101517200

30. Koibuchi N, Liu Y, Fukuda H, Takeshita A, Yen PM, Chin WW. ROR $\alpha$ augments thyroid hormone receptor-mediated transcriptional activation. Endocrinology (1999) 140:1356-64. doi:10.1210/endo.140.3.6562

31. Iwasaki T, Miyazaki W, Takeshita A, Kuroda Y, Koibuchi N. Polychlorinated biphenyls suppress thyroid hormone-induced transactivation. Biochem Biophys Res Commun (2002) 299:384-8. doi:10.1016/S0006-291X(02)02659-1

32. Kimura-Kuroda J, Nagata I, Kuroda Y. Hydroxylated metabolites of polychlorinated biphenyls inhibit thyroid-hormone-dependent extension of cerebellar Purkinje cell dendrites. Dev Brain Res (2005) 154:259-63. doi:10.1016/j. devbrainres.2004.11.004

33. Feng M, Fan Y-Z, Ma X-J, Li J-X, Yang X-G. The gadolinium-based contrast agent Omniscan ${ }^{\circledR}$ promotes in vitro fibroblast survival through in situ precipitation. Metallomics (2015) 7:1103-10. doi:10.1039/C5MT00055F

34. Farwell AP, Dubord-tomasetti SA, Pietrzykowski AZ, Stachelek SJ, Leonard JL. Regulation of cerebellar neuronal migration and neurite outgrowth by thyroxine and 3, 3', 5'-triiodothyronine. Dev Brain Res (2005) 154:121-35. doi:10.1016/j.devbrainres.2004.07.016

35. Fretellier N, Idée J-M, Dencausse A, Karroum O, Guerret S, Poveda N, et al. Comparative in vivo dissociation of gadolinium chelates in renally impaired rats: a relaxometry study. Invest Radiol (2011) 46:292-300. doi:10.1097/ RLI.0b013e3182056ccf

36. Yu L, Iwasaki T, Xu M, Lesmana R, Xiong Y, Shimokawa N, et al. Aberrant cerebellar development of transgenic mice expressing dominant-negative thyroid hormone receptor in cerebellar Purkinje cells. Endocrinology (2015) 156:1565-76. doi:10.1210/en.2014-1079

37. Kuno-Murata M, Koibuchi N, Fukuda H, Murata M, Chin WW. Augmentation of thyroid hormone receptor-mediated transcription by $\mathrm{Ca} 2+/$ calmodulin-dependent protein kinase type IV. Endocrinology (2000) 141:2275-8. doi:10.1210/en.2002-220612

38. Davis PJ, Goglia F, Leonard JL. Nongenomic actions of thyroid hormone. Nat Rev Endocrinol (2016) 12:111-21. doi:10.1097/01.med.0000152036.70617.1e

39. James Cao H, Lin H-Y, Luidens MK, Davis FB, Davis PJ. Cytoplasm-tonucleus shuttling of thyroid hormone receptor- $\beta 1(\operatorname{Tr} \beta 1)$ is directed from a plasma membrane integrin receptor by thyroid hormone. Endocr Res (2009) 34:31-42. doi:10.1080/07435800902911810

40. Lin H, Sun M, Tang H, Lin C, Luidens MK, Mousa SA, et al. L-Thyroxine vs. 3,5,3'-triio-L-thyronine and cell proliferation: activation of mitogen-activated protein kinase and phosphatidylinositol 3-kinase. Am J Physiol Cell Physiol (2009) 296:C980-91. doi:10.1152/ajpcell.00305.2008

41. Burtea C, Laurent S, Murariu O, Rattat D, Toubeau G, Verbruggen A, et al. Molecular imaging of $\alpha \mathrm{v} \beta 3$ integrin expression in atherosclerotic plaques 
with a mimetic of RGD peptide grafted to Gd-DTPA. Cardiovasc Res (2008) 78:148-57. doi:10.1093/cvr/cvm115

42. Bergh JJ, Lin HY, Lansing L, Mohamed SN, Davis FB, Mousa S, et al. Integrin $\alpha v \beta 3$ contains a cell surface receptor site for thyroid hormone that is linked to activation of mitogen-activated protein kinase and induction of angiogenesis. Endocrinology (2005) 146:2864-71. doi:10.1210/en. 2005-0102

43. Herrera-Molina R, Frischknecht R, Maldonado $H$, Seidenbecher CI, Gundelfinger ED, Hetz C, et al. Astrocytic $\alpha v \beta 3$ integrin inhibits neurite outgrowth and promotes retraction of neuronal processes by clustering thy- 1 . PLoS One (2012) 7:e34295. doi:10.1371/journal.pone.0034295

44. Wermuth PJ, Jimenez SA. Induction of a type I interferon signature in normal human monocytes by gadolinium-based contrast agents: comparison of linear and macrocyclic agents. J Transl Immunol (2013) 175:113-25. doi:10.1111/ cei. 12211

45. Ishitobi H, Mori K, Yoshida K, Watanabe C. Effects of perinatal exposure to low-dose cadmium on thyroid hormone-related and sex hormone receptor gene expressions in brain of offspring. Neurotoxicology (2007) 28:790-7. doi:10.1016/j.neuro.2007.02.007

46. Telgmann L, Sperling M, Karst U. Determination of gadolinium-based MRI contrast agents in biological and environmental samples: a review. Anal Chim Acta (2013) 764:1-16. doi:10.1016/j.aca.2012.12.007

Conflict of Interest Statement: The authors declare that the research was conducted in the absence of any commercial or financial relationships that could be construed as a potential conflict of interest.

Copyright (0) 2016 Ariyani, Iwasaki, Miyazaki, Khongorzul, Nakajima, Kameo, Koyama, Tsushima and Koibuchi. This is an open-access article distributed under the terms of the Creative Commons Attribution License (CC BY). The use, distribution or reproduction in other forums is permitted, provided the original author (s) or licensor are credited and that the original publication in this journal is cited, in accordance with accepted academic practice. No use, distribution or reproduction is permitted which does not comply with these terms. 